\title{
Pemetaan Arah Desain Rice Box untuk Pengguna Di Indonesia
}

\author{
Wildan Aulia ${ }^{1}$ \\ Desain Produk, Fakultas Teknik dan Desain, Institut Teknologi Sains Bandung, Cikarang, Indonesia \\ E-mail:wildan@itsb.ac.id
}

Informasi naskah:

Diterima

20 Desember 2019

Direvisi

11 Januari 2020

Disetujui terbit

14 Februari 2020

Diterbitkan

28 Februari 2020

\begin{abstract}
In 2011 and 2016, the author had been designed a rice box based on user aspect. The result indicated the change of rice box product design in form of dimension/ load capacity. This indication then followed by continued study in order to find the comprehensive design of rice box development. This research is focused on design mapping based on design direction of rice box that had been done in 2011, 2016 and 2019, also perceptual mapping method on existing rice box products. The aim is to find the tendency user preference to rice box design. The result showed that the significant value for user preference is rice box with capacity of $12 \mathrm{~kg}$ and slowly leave the rice box with capacity of $30 \mathrm{~kg}$. This study also argued that there is an implication of rice consumption changing. The result is hopefully could become the reference in rice box design based on mapping result that can be applied by industrial stakeholder.
\end{abstract}

Key words: industrial product design, rice box, design preference

\section{PENDAhuluan}

Pemetaan arah desain dilakukan untuk mencari pasar paling potensial dari sebuah produk agar produk terserap maksimal dan tepat sasaran. Pemetaan arah desain bertujuan untuk membuka ruang pengembangan desain yang tepat untuk memperoleh pangsa pasar sesuai targetnya. Penelitian ini berangkat dari pengamatan penulis terhadap desain rice box yang ditawarkan produsen dan perubahan penggunaan rice box oleh konsumen. Konsumsi beras masyarakat yang semakin sedikit mengakibatkan masyarakat lebih memilih rice box berukuran kecil. Fenomena ini mengindikasikan bahwa rekomendasi desain rice box yang penulis usulkan sebelumnya, yaitu bahwa rice box harus berkapasitas $25 \mathrm{~kg}^{1}$, sudah tidak relevan lagi. 
Masyarakat keluarga kecil berusia muda di perkotaan memiliki kecenderungan mengonsumsi beras yang sedikit karena jumlah anggota keluarga yang sedikit serta pilihan untuk mengonsumsi makanan pokok selain beras yang mudah diakses. Selain itu, dengan pola aktifitas sebagai pekerja, mereka hanya memiliki waktu efektif untuk memasak beras di rumahnya hanya di pagi hari dan malam hari. Akibatnya stok beras untuk kebutuhan sehari-hari tidak besar. Rice box berukuran besar menjadi tidak relevan. Harga rice box yang berada di atas harga barang-barang wadah menjadi tidak terjangkau (affordable) karena fungsinya dapat digantikan oleh wadah biasa.

Penulis juga mengamati bahwa desain rice box baru yang ditawarkan produsen cenderung stylish. Hal ini dimungkinkan karena hunian masa kini lebih berkonsep space sehingga mendorong penghuni untuk menandai/memfungsikan area dalam rumah berdasarkan pada pengelompokkan benda-benda di rumahnya. Akibatnya bila sebuah perabot dapur (kitchenware) diberi desain yang tidak cocok dengan desain perabot dapur lainnya, maka akan terjadi kemungkinan pengguna tidak akan menempatkan produk tersebut di dapur karena dinilai bukan sebagai kelompok perabotan dapur. Hal ini bukan sesuatu yang salah selama desain dikonsepkan untuk dikategorikan sebagai produk rumah tangga (household appliances).

Sebuah produk dapat diterima oleh pasar bila dibuat sesuai dengan segmentasi pasarnya. Segmentasi pasar dibuat dengan mengidentifikasi kebutuhan dan keinginan calon konsumen dengan memahami perilaku konsumen secara strategis dan tajam ${ }^{2}$. Sebuah produk dalam perspektif pengguna bisa dikatakan berhasil bila memenuhi dua aspek, yaitu aspek fungsi dan aspek emosi ${ }^{34)}$. Dari dua rujukan tersebut, penulis memahami bahwa aspek fungsi identik dengan kebutuhan dan aspek emosi identik dengan keinginan di mana hal tersebut dapat diidentifikasi melalui pengamatan terhadap perilaku konsumen terhadap produk. Produk memiliki tiga sifat yang harus dianalisis untuk memutuskan karakter produk yang cocok untuk konsumen, yaitu features (keistimewaan apa yang ditawarkan produk), function (bagaimana sebuah produk digunakan), dan benefits (bagaimana produk menawarkan kepuasan kepada pengguna) ${ }^{5)}$. Tiga hal ini adalah penting agar produk dapat menemukan celah di antara kompetitor. Sebuah produk dapat menawarkan benefits bila kebutuhan sudah terpenuhi ${ }^{6)}$. Penulis memahami bahwa menawarkan alternatif produk pada konsumen untuk sebuah fungsi yang telah diatasi oleh produk sebelumnya, haruslah mengarah kepada aspek features dan benefits sebuah produk. Dalam desain produk industri, kebutuhan juga berarti berupa kebutuhan estetika yang meliputi penampilan, imej, dan daya tarik visual ${ }^{7)}$. Aspek-aspek tersebut merupakan hal penting agar sebuah produk dapat bersaing dalam pasar yang stabil. Dalam hal ini, produk dapat ditempatkan pada sebuah celah pasar melalui diagram perceptual mapping sebagai upaya untuk memposisikan produk di antara kompetitor secara terukur ${ }^{8)}$. 
Berdasar pada hal tersebut, penulis membangun hipotesis awal bahwa arah desain rice box mengikuti kecenderungan perubahan perilaku pengguna dalam mengonsumsi beras. Hipotesis ini harus dibuktikan dengan analisa perubahan perilaku pengguna rice box serta memetakan desain rice box yang ditawarkan produsen dewasa ini untuk membangun hubungan terhadap asumsi yang dibangun menjadi sebuah rekomendasi desain.

\section{METODE}

Metode penelitian bersifat kuantitatif kualitatif. Kuisioner disebar kepada responden individu yang berbeda namun dengan tipe responden yang sama, yaitu pengguna rice box di daerah perkotaan yang dipilih secara purposive sampling dengan jumlah 30 responden. Jumlah responden ditentukan dengan mengacu pada kecukupan jumlah responden dalam statistik ilmu sosial dengan syarat harus selektif dan terpercaya. Dengan demikian, maka responden hanyalah pengguna rice box yang dipilih acak di tiga kota besar sebagai gambaran populasi masyarakat kota kultur pekerja, yaitu Jakarta, Tangerang dan Bandung dengan kriteria telah berkeluarga di rentang usia produktif antara 25 hingga 45 tahun. Hal ini dilakukan secara konsisten dari pengujian pertama tahun 2011, tahun 2016 dan tahun 2019 sehingga menjadi terukur. Hasil kuisioner diolah secara statistik deskriptif melalui teknik perhitungan frequency distribution nominal.

Penetapan arah desain (design direction) dilakukan melalui perceptual mapping untuk memetakan kecenderungan perubahan desain rice box mengacu pada produk yang sudah ada. Produk dipetakan berdasarkan tahun dipasarkan dan kapasitas/model. Diagram disajikan dalam format kuadran yang dibagi dengan tahun $(<2010$ dan $>2010)$ dan kapasitas rice box (besar: $>18 \mathrm{~kg}$ dan kecil: $<18 \mathrm{~kg}$ ). Data diperoleh melalui web brochure pada situs penjualan dan produsen rice box.

Tabel 1. Variabel penelitian mengenai kebutuhan pengguna terhadap rice box

\begin{tabular}{|c|c|c|}
\hline No. & Variabel & Tujuan pengujian \\
\hline 1 & Jumlah anggota keluarga & $\begin{array}{l}\text { Mengidentifikasi kebutuhan tipe rice box berdasarkan } \\
\text { kapasitasnya }\end{array}$ \\
\hline 2 & Pengisian beras & $\begin{array}{l}\text { Mengidentifikasi frekuensi pengisian beras dalam satu } \\
\text { bulan }\end{array}$ \\
\hline 3 & Kuantiti pengisian & $\begin{array}{l}\text { Mengidentifikasi kuantiti beras dalam setiap kali } \\
\text { pengisian }\end{array}$ \\
\hline 4 & Kapasitas rice box & $\begin{array}{l}\text { Mengidentifikasi penggunaan tipe rice box terbanyak } \\
\text { berdasar pada kapasitas penampungannya }\end{array}$ \\
\hline 5 & Jangka waktu simpan beras & $\begin{array}{l}\text { Mengidentifikasi jangka waktu menyimpan beras dalam } \\
\text { satu kali pengisian beras ke dalam rice box }\end{array}$ \\
\hline 6 & Tipe rice box & $\begin{array}{l}\text { Mengidentifikasi pertimbangan masyarakat dalam } \\
\text { memilih model rice box }\end{array}$ \\
\hline
\end{tabular}


Tabel 2. Variabel penelitian mengenai perlakuan pengguna terhadap rice box

\begin{tabular}{|c|c|c|}
\hline No. & Variabel & Tujuan pengujian \\
\hline 1 & Menyimpan rice box & $\begin{array}{l}\text { Mengidentifikasi kecenderungan pengguna dalam } \\
\text { mengkategorikan rice box terhadap perabotan rumah } \\
\text { lainnya }\end{array}$ \\
\hline 2 & Menempatkan rice box & $\begin{array}{l}\text { Mengidentifikasi kecenderungan pengguna dalam } \\
\text { menyimpan rice box }\end{array}$ \\
\hline 3 & Frekuensi mengambil beras & $\begin{array}{l}\text { Mengidentifikasi seberapa sering pengguna } \\
\text { mengoperasikan rice box dalam satu hari }\end{array}$ \\
\hline 4 & Mengambil beras & $\begin{array}{l}\text { Mengidentifikasi cara mengambil beras dari rice box } \\
\text { dikaitkan dengan sistem operasional yang ada di rice box }\end{array}$ \\
\hline 5 & Menakar beras & $\begin{array}{l}\text { Mengidentifikasi cara menakar beras dikaitkan dengan } \\
\text { satuan ukuran yang ada pada produk rice box }\end{array}$ \\
\hline 6 & $\begin{array}{l}\text { Penggunaan sistem } \\
\text { operasional rice box }\end{array}$ & Mengidentifikasi keefektifan sistem operasional rice box \\
\hline
\end{tabular}

\section{PEMBAHASAN DAN DISKUSI}

\subsection{Perbandingan Data Tahun 2011, 2016 dan 2019 Mengenai Kebutuhan Pengguna terhadap Rice box}

Kecenderungan umum yang terjadi adalah jumlah anggota keluarga semakin sedikit. Data tahun 2011 menunjukkan bahwa persentase jumlah anggota 5-6 orang merupakan yang terbanyak, yaitu sebanyak 47\%. Data tahun 2016 justru menunjukkan sebaliknya bahwa responden dengan jumlah anggota keluarga 3-4 orang merupakan yang terbanyak, mencapai 53\%, melebihi persentase jumlah anggota keluarga 5-6 orang. Sedangkan di tahun 2019, jumlah anggota keluarga 3-4 adalah sebanyak 44,4\% dan jumlah anggota keluarga 5-6 orang sebanyak 25,9\%. Selain itu jumlah anggota keluarga dua orang meningkat menjadi $17 \%$ pada 2016 dan 14,8\% pada 2019 dibanding 2011 yang hanya sebanyak $7 \%$. Hal ini membangun asumsi konsumsi beras masyarakat yang semakin sedikit karena jumlah keluarga yang semakin sedikit.

Data tahun 2011 menunjukkan bahwa 64\% responden mengisi beras ke dalam rice box satu kali dalam satu bulan. Persentase ini meningkat di tahun 2016 menjadi 70\%. Data tahun 2016 juga menunjukkan tidak ada responden yang mengisi beras tiga atau empat kali dalam sebulan, sedangkan data tahun 2011 menunjukkan 7\% responden mengisi beras tiga kali dalam sebulan dan $3 \%$ responden mengisi beras empat kali dalam sebulan. Perubahan signifikan terjadi di tahun 2019, di mana pengisian beras satu kali dalam sebulan menurun menjadi 33,3\%. Di tahun 2019, masyarakat yang mengisi beras dua kali dalam sebulan mencapai 51,9\%, jauh di atas persentase pada tahun 2011 sebesar 23\% dan tahun 2016 sebesar $27 \%$. Hal ini mengindikasikan perubahan pola stok beras masyarakat di rumahnya. 
Data tahun 2011 menunjukkan bahwa 50\% responden mengisikan beras sebanyak 11$25 \mathrm{~kg}$ setiap kali pengisian. Hal yang sama meningkat pada tahun 2016 meskipun tidak signifikan, yaitu sebesar 57\%. Terdapat penurunan jumlah responden yang mengisi jumlah beras sebanyak $26-50 \mathrm{~kg}$ setiap kali pengisian, dimana tahun 2011 terdapat $17 \%$ responden, sedangkan tahun 2016 hanya 3\% responden saja. Data tahun 2016 juga menunjukkan tidak ada lagi responden yang mengisi beras lebih dari $50 \mathrm{~kg}$ di setiap kali pengisian, sedangkan data tahun 2011 menunjukkan sebanyak 3\% responden masih melakukan pengisian beras lebih dari $50 \mathrm{~kg}$ dalam setiap kali pengisian. Perubahan signifikan terlihat pada tahun 2019, di mana mayoritas responden sebesar $63 \%$ mengisi beras sebanyak 6-10 kg untuk satu kali pengisian, dan 29,6\% bahkan mengisikan beras tidak lebih dari $5 \mathrm{~kg}$ setiap kali pengisian. Hal ini mengindikasikan penggunaan rice box yang tidak lagi berkapasitas besar sekaligus mengonfirmasi data perubahan pola stok beras.

Data tahun 2011 menunjukkan bahwa responden yang menggunakan rice box berkapasitas $28 \mathrm{~kg}$ adalah sebanyak 36\%. Data tahun 2016 menunjukkan peningkatan signifikan jumlah responden yang menggunakan rice box berkapasitas $28 \mathrm{~kg}$, yaitu menjadi 63\% namun kembali menurun di tahun 2019 menjadi 19,2\%. Data tahun 2016 menunjukkan penurunan jumlah responden yang menggunakan rice box berkapasitas $18 \mathrm{~kg}$ dibanding tahun 2011, yaitu dari 33\% pada tahun 2011 manjadi 7\% di tahun 2016 meskipun kembali meningkat menjadi $23,1 \%$ di tahun 2019. Terjadi peningkatan pemilihan rice box berkapasitas $12 \mathrm{~kg}$, yaitu tahun 2011 sebanyak 17\%; tahun 2016 sebanyak 27\%; dan tahun 2019 melonjak signifikan menjadi 50\%. Selain itu data tahun 2016 menunjukkan tidak ada lagi responden yang menggunakan rice box berkapasitas 60 $\mathrm{kg}$, dimana data tahun 2011 menunjukkan bahwa masih ada responden yang menggunakan rice box berkapasitas $60 \mathrm{~kg}$, yaitu sebesar $7 \%$. Begitupun terjadi penurunan pemilihan rice box berkapasitas $38 \mathrm{~kg}$. Data tahun 2016 dan tahun 2019 menunjukkan 3\% responden memilih rice box berkapasitas $38 \mathrm{~kg}$, dimana sebelumnya di tahun 2011 terdapat 7\% responden yang memilih rice box berkapasitas $38 \mathrm{~kg}$. Hal ini mengindikasikan bahwa kecenderungan preferensi pengguna bergeser menjadi rice box berkapasitas kecil (12 kg).

Data menunjukkan bahwa di tahun 2011, 2016 dan 2019 jumlah responden yang menyimpan persediaan beras untuk jangka waktu satu bulan masih merupakan yang paling dominan, yaitu masing-masing 50\%, 64\% dan 51,9\%. Dengan mempertimbangkan data mengenai pemilihan model rice box, maka data ini juga mengonfirmasi jumlah konsumsi beras yang menurun sebagai akibat dari jumlah keluarga yang semakin sedikit.

Data tahun 2011, 2016 dan 2019 menunjukkan bahwa pertimbangan memilih tipe rice box berdasarkan fungsi masih merupakan pertimbangan paling dominan bahkan cenderung meningkat, yaitu masing-masing 67\%, 57\% dan 76,9\%. Terjadi peningkatan jumlah responden yang memilih tipe rice box berdasarkan kapasitas penampungan secara signifikan. Data tahun 2016 menunjukkan sebanyak 40\% responden memilih tipe rice box berdasarkan kapasitas penampungan, dimana pada tahun 2011 hanya 13\% responden saja, 
meskipun kembali menurun di tahun 2019, yaitu menjadi 15,4\%. Hal yang menarik adalah tidak ada lagi responden yang memilih rice box berdasarkan model, dimana pada tahun 2011 10\% responden memilih berdasarkan model. Hal ini mengindikasikan bahwa styling pada rice box tidaklah fundamental dalam meningkatkan pertimbangan pengguna dalam memilih rice box.

\subsection{Perbandingan Data Tahun 2011, 2016 dan 2019 mengenai Perlakuan Pengguna terhadap Rice box}

Dapur masih merupakan tempat yang umum dipilih responden untuk menyimpan rice box dan tidak mengalami perubahan kecenderungan yang signifikan. Beberapa responden menyimpan rice box di ruang makan dengan persentase yang kecil, yaitu tahun 2011 terdapat 4\% responden, tahun 2016 terdapat 14\% responden, dan tahun 2019 terdapat 3,7\% responden. Data tahun 2016 juga menunjukkan terdapat 3\% responden yang menyimpan rice box di ruang keluarga, dimana di tahun 2011 dan tahun 2019 tidak ada responden yang memilih ruang keluarga untuk menyimpan rice box. Data tahun 2016 dan tahun 2019 menunjukkan tidak ada responden yang menyimpan rice box di gudang, sedangkan pada 2011 sebanyak 3\% responden menyimpan rice box di gudang. Hal ini menegaskan bahwa rice box terkategorikan sebagai perabot dapur.

Data tahun 2016 menunjukkan bahwa 20\% responden menempatkan rice box di tempat tinggi, dan semakin bertambah di tahun 2019, yaitu mencapai 29,6\%, di mana di tahun 2011 hanya $10 \%$ responden saja. Hal ini berbanding terbalik dengan jumlah responden yang menempatkan rice box di lantai. Pada tahun 2011 sebanyak 87\% responden menyimpan rice box di lantai, sedangkan pada tahun 2016 menurun menjadi $77 \%$ responden dan semakin menurun di tahun 2019 menjadi 66,9\%. Menariknya adalah bahwa di tahun 2019 sebagian responden yang menempatkan rice box di lantai sebanyak 22,2\% memilih untuk menempatkannya di tempat tersembunyi, sedangkan di tahun 2011 dan 2016 hanya $7 \%$ responden saja yang memilih jawaban tersebut. Hal ini mengindikasikan bahwa pengguna tidak lagi menilai rice box sebagai perabot yang ditampilkan untuk mengisi ruang.

Data tahun 2016 menunjukkan bahwa 70\% responden mengambil beras sebanyak satu kali dalam satu hari dari dalam rice box dan meningkat di tahun 2019 menjadi 77,8\%, sedangkan pada tahun 2011 hanya 40\% responden yang memilih jawaban tersebut. Sedangkan yang mengambil beras dua kali dalam satu hari dari dalam rice box menurun dari 47\% di tahun 2011 menjadi 30\% di tahun 2016 dan semakin menurun menjadi 22,2\% di tahun 2019. Hal ini mengindikasikan pola konsumsi beras yang bergeser menjadi semakin sedikit.

Berjongkok masih merupakan cara mengambil beras yang paling umum dilakukan, yaitu 53\% responden pada tahun 2011 , 67\% responden pada tahun 2016, dan 48,1\% responden pada tahun 2019. Yang patut diperhatikan adalah terjadi peningkatan persentase cara mengambil beras dengan berdiri, yaitu 7\% responden pada tahun 2011 , 
melonjak menjadi $27 \%$ responden dan semakin naik menjadi 33,3\% di tahun 2019 . Hal ini mengidikasikan penggunaan rice box ukuran kecil yang dapat ditempatkan di atas sesuatu sekaligus mengonfirmasi data mengenai penempatan rice box.

Cara menakar beras pada rice box umumnya dilakukan dalam dua cara, yaitu menggunakan takaran yang tersedia pada rice box atau menggunakan wadah/takaran sendiri. Menggunakan takaran pada rice box masih merupakan cara yang paling banyak dilakukan oleh pengguna. Data menunjukkan bahwa responden yang menggunakan cara ini adalah sebesar $73 \%$ pada tahun 2011, 50\% pada tahun 2016, dan 63\% pada tahun 2019 . Hal ini mengindikasikan bahwa fungsi takaran pada rice box cukup efektif meskipun perlu lebih disesuaikan dengan kebiasaan masyarakat. Desain rice box perlu mempertimbangkan kebiasaan pengguna menakar beras dengan wadah/takaran sendiri, karena persentase untuk hal ini cukup banyak, yaitu $23 \%$ pada tahun $2011,50 \%$ pada tahun 2016 , dan $37 \%$ pada tahun 2019. Hal ini mengindikasikan bedanya satuan takaran yang diterapkan pada produk dengan kebiasaan masyarakat, misal antara satuan gram dengan cup.

Data tahun 2016 menunjukkan bahwa penggunaan sistem operasional pada rice box menurun drastis daripada di tahun 2011, yaitu 53\% responden menyatakan kadang-kadang (lebih banyak daripada responden yang menjawab selalu). Responden yang memilih jawaban ini pada tahun 2011 hanya 7\% responden. Sedangkan tahun 2019 kecenderungan tersebut masih bertahan meskipun mengalami perubahan kecil. Responden yang menjawab kadang-kadang adalah sebanyak 29,6\% dan yang menjawab selalu sebanyak 44,4\%. Hal ini menarik karena mengindikasikan bahwa desain rice box mengalami penurunan keberhasilan fungsi operasional yang bisa jadi diakibatkan oleh desain rice box yang semakin kecil. Pengguna merasa lebih mudah untuk menggunakannya seperti ember/wadah. Bedanya ukuran satuan takaran dapat saja mempengaruhi pengguna untuk meninggalkan sistem pengeluaran beras. Hingga saat ini semua rice box masih menggunakan satuan gram. Akan lebih efektif bila satuan takaran pada rice box dapat terintegrasi dengan ukuran cup pada produk rice cooker.

\subsection{Perceptual Mapping}

Untuk mempertajam hasil kuisioner, maka diperlukan studi terhadap kecenderungan desain rice box. Bila hasilnya mendukung hasil kuisioner, maka hasil studi dapat menjadi arah desain (design dirrection) untuk pengembangan desain rice box selanjutnya. Perceptual mapping dibangun dari image yang dikumpulkan dari web brochure merk rice box dominan di pasaran. Kecenderungan yang diperoleh dari hasil kuisioner untuk dikonfirmasi melalui perceptual mapping terkait dengan desain produk adalah sebagai berikut:

1. Penggunaan rice box yang tidak lagi berkapasitas besar.

2. Terdapat peningkaran penggunaan rice box berkapasitas $12 \mathrm{~kg}$.

3. Penggayaan pada rice box tidaklah menjadi pertimbangan utama memilih tipe rice box.

4. Rice box dikategorikan sebagai perabot dapur. 
5. Terdapat indikasi bahwa pengguna tidak menilai rice box sebagai perabot yang ditampilkan untuk mengisi ruang.

6. Rice box ukuran kecil disimpan di atas sesuatu, tidak diletakkan di lantai.

7. Terdapat perbedaan satuan takaran yang diterapkan pada produk dengan kebiasaan masyarakat, terutama antara satuan gram dengan cup.

8. Pengguna tidak terlalu menggunakan sistem mekanik pada produk untuk mengambil beras dari rice box.

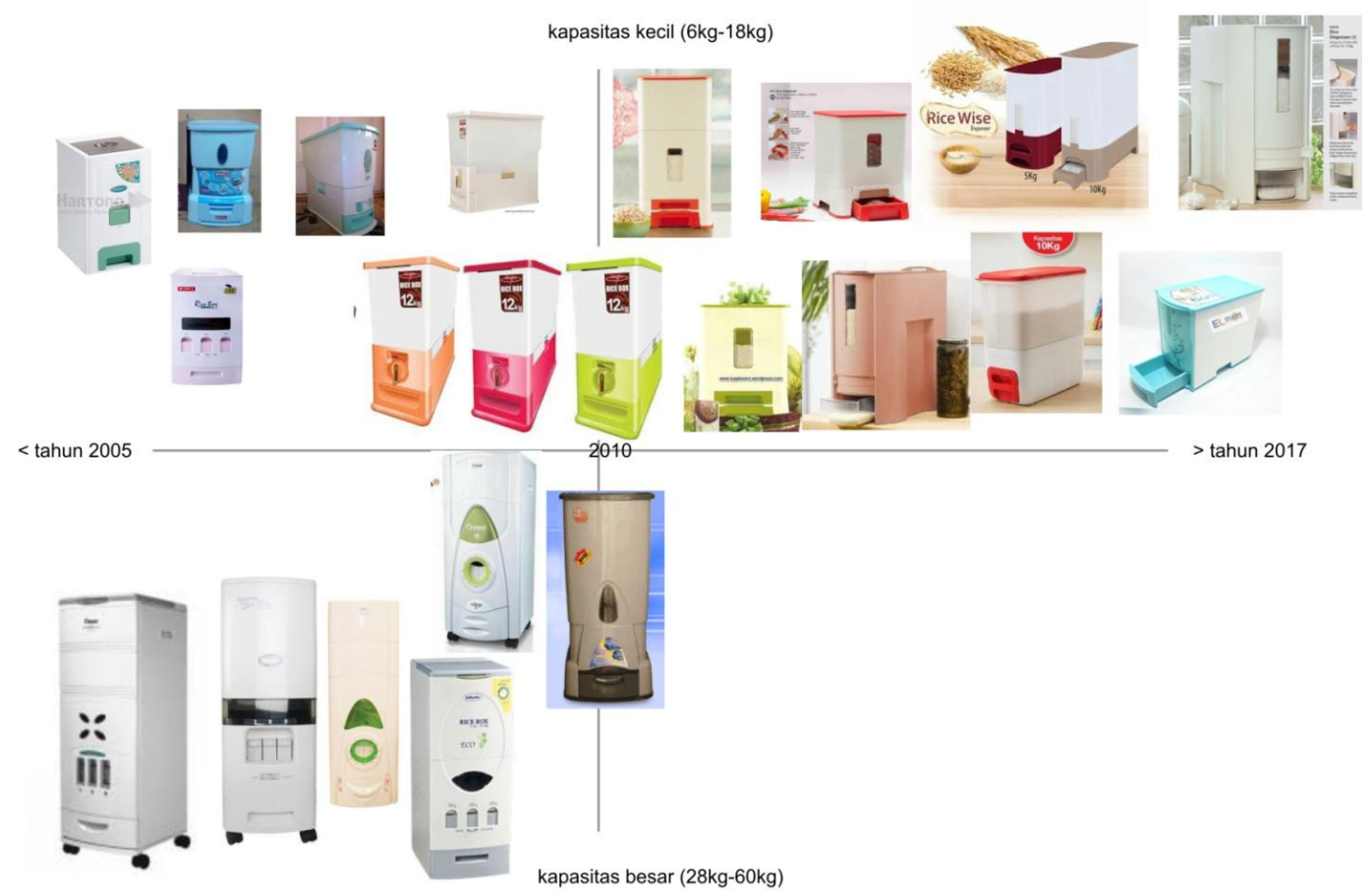

Gambar 13. Diagram perceptual mapping

Diagram memunculkan beberapa simpulan sebagai konfirmasi hasil kuisioner, yaitu:

1. Dalam rentang tahun 2010 hingga 2017, dua merek menawarkan desain baru berkapasitas kurang dari $14 \mathrm{~kg}$.

2. Tidak ada desain rice box baru yang ditawarkan produsen dengan kapasitas lebih dari $18 \mathrm{~kg}$ di rentang waktu 2010 - 2017.

3. Dua merk menawarkan desain rice box baru berkapasitas $5 \mathrm{~kg}$ dan $7 \mathrm{~kg}$ di tahun 2017 .

4. Bentuk rice box di rentang waktu tahun 2010 - 2017 lebih stylish dan variatif secara tampilan muka dan konfigurasinya dibanding bentuk rice box di rentang waktu tahun 2005 - 2010.

5. Desain rice box baru yang ditawarkan produsen dirancang dengan mengolah tampilan produk yang baru dan variatif, baik bentuk ataupun warna, namun tidak dalam sistem pengoperasian.

6. Semua rice box menggunakan satuan gram.

7. Desain rice box kecil dirancang untuk disimpan di atas meja. 
8. Beberapa merk masih menjual rice box dengan usia desain yang lebih dari 15 tahun.

9. Produk rice box rentang tahun 2005 - 2010 berbahan besi dengan kombinasi plastik. Sedangkan rice box rentang tahun 2010 - 2017 berbahan full plastik.

Hasil perceptual mapping terbukti mendukukung hasil komparasi data kuisioner. Mengacu pada hasil kuisioner dan perceptual mapping maka arah pengembangan rice box adalah rice box berkapasitan di bawah $18 \mathrm{~kg}$ dengan berfokus pada fungsi. Dengan demikian maka hipotesis terbukti positif. Terdapat beberapa hal yang tidak cocok antara desain rice box yang ditawarkan produsen dengan kebutuhan masyarakat, yaitu:

1. Penggayaan pada rice box belum menjadi poin penting terhadap pertimbangan pengguna memilih tipe rice box.

2. Satuan gram pada sistem mekanik rice box tidak digunakan oleh mayoritas pengguna.

Selain hal tersebut, mengacu pada data kuisioner yang diperoleh bahwa tidak ada responden yang menyimpan beras lebih dari satu bulan, maka rice box yang ada sudah memenuhi fungsinya tanpa harus mempertimbangkan faktor keawetan beras. Hal ini dikarenakan beras merupakan bahan makanan yang tahan lama dan dapat bertahan hingga enam bulan penyimpanan dengan syarat disimpan di tempat yang kering, tertutup, dan di tempat dengan bahan yang tidak berkarat ${ }^{8)}$. Tempat yang basah dan lembab akan menimbulkan kutu dan menyebabkan tumbuhnya jamur. Pertimbangan ini menjadi dasar untuk memilih material rice box.

\subsection{Arah Desain}

Arah desain ditetapkan berdasar pada poin-poin hasil perceptual mapping di atas, yaitu:

1. Desain berkapasitas dalam rentang $5 \mathrm{~kg}-18 \mathrm{~kg}$.

2. Desain dirancang untuk dapat diletakkan di atas meja. Poin ini menjadi bahan pertimbangan penentuan dimensi kasar dan bentuk dasar.

3. Bentuk dasar kotak adalah bentuk dasar yang direkomendasikan dengan pertimbangan mudah diletakkan di atas meja. Dimensi dapat bervariasi untuk mengurangi ukuran panjang tinggi lebar dengan perhitungan perbandingan/proporsi yang baik.

4. Rice box disarankan berimej homey dengan tampilan yang baik tanpa perlu penggayaan yang terlalu banyak.

5. Menggunakan warna pastel.

6. Material menggunakan plastik untuk menghindari karat dan lembab.

7. Material full plastic juga ditujukan untuk mencapai bentuk dengan garis lengkung yang baik.

8. Sistem pengeluaran beras tidak harus menggunakan sistem mekanik dan tidak perlu menggunakan satuan gram.

9. Rice box harus memiliki round corner yang besar agar terlihat baik sebagai produk yang bisa diletakkan di atas meja dan dapat terkategorikan sebagai kitchen accessories oleh pengguna

10. Produk harus ergonomis. 


\section{KESIMPULAN}

1. Terjadi perubahan persepsi masyarakat mengenai klasifikasi perabotan rumah di mana rice box tidak lagi dinilai sebagai perabotan dapur.

2. Zoning di rumah model sekarang dengan konsep space juga mempengaruhi pengelompokan produk. Perabotan dapur akan membentuk zona dapur. Saat tampilan rice box menjadi stylish maka rice box tidak cocok (fit) lagi dengan kelompok peralatan dapur namun justru mengarah menjadi asesoris dapur. Hal ini terjadi karena rice box kecil mendorong pengguna menempatkannya di atas meja dan menjadikan rice box harus memiliki tampilan yang baik karena menjadi sebuah produk yang terekspos. Namun demikian, hasil kuisioner mengenai variabel ini menunjukkan hasil berbeda. Variasi bentuk yang banyak ditawarkan produsen, sebetulnya tidak menjadi pertimbangan dominan konsumen untuk memilih tipe rice box, namun desain/style diperlukan untuk membedakan tampilan antar kompetitor dan untuk menjaga brand image produk. Hal ini tentu signifikan untuk menjaga market. Berkaitan dengan hal tersebut, disarankan agar desain tidak mengolah tampilan secara over design.

3. Rice box masih berupa produk tersier karena fungsinya sebagai wadah masih mudah tergantikan oleh produk lain. Hal ini mengakibatkan segmen menengah bawah tidak memandang rice box sebagai kebutuhan utama. Harga Rp.300,000,- masih terlalu mahal untuk sebuah wadah beras karena box container dengan harga di bawah Rp.100,000,- sudah dianggap menyelesaikan masalah. Dengan demikian maka segmen paling potensial adalah kalangan menengah atas dengan harga di atas Rp.400.000,- atau justru dengan menekan harga di bawah Rp.200,000,- untuk segmen kalangan menengah bawah.

4. Rekomendasi desain diarahkan pada kapasitas dan tampilan rice box sebagai dua hal yang harus diperhatikan untuk memaksimalkan features dan benefit dari produk rice box.

5. Hasil penelitian merupakan rekomendasi pengembangan rice box untuk mencapai segmen pasar yang terukur di antara kompetitor yang ada. Penelitian dapat terus dikembangkan untuk mencapai standarisasi produk secara komprehensif, baik dari sisi material, skema produksi dan penetapan komponen, skema perakitan, hingga skema distribusi dan pengemasan.

\section{UCAPAN TERIMA KASIH}

Penulis mengucapkan terima kasih kepada LPPM ITSB dan semua pihak yang sudah membantu dalam kelancaran penelitian yang dilakukan. 


\section{DAFTAR PUSTAKA}

1) Aulia, Wildan. (2016). Pengembangan Desain Rice box yang Mengacu pada Prilaku Pengguna dalam Menyimpan Beras dan Preferensi Secara Visual terhadap Produk Rice box yang Sudah Ada. Jurnal Teknologi Proses dan Inovasi Industri, E-ISSN 25301236, Vol.1, Nomor 1, hal 15 - 22. Kementerian Perindustrian. Surabaya: Balai Riset dan Standardisasi Industri.

2) Kotler, Philip \& Keller, Kevin L. (2012). Marketing Management. England: Pearson.

3) Norman, Donald A. (2002). The Design of Everyday Things. United States of America: Basic Paperback.

4) Norman, Donald A. (2004). Emotional Design: Why We Love (or Hate) Everyday Things. New York: Basic Books.

5) Crawford, Merle \& Di Benedetto, Anthony. (2008). New Products Management. Singapore: McGraw-Hill International Edition.

6) Ulrich, Karl T. \& Eppinger, Steven. (2008). Product Design and Development. Singapore: McGraw-Hill International Edition.

7) Milto, Alex \& Rodgers, Paul. (2013). Research Methods for Product Design. China: Laurence King Publishing.

8) -. (2015). Disimpan Terlalu Lama, Beras Jadi Tak Layak Konsumsi. Artikel Koran Jateng Raya Metro Semarang 02/07/2015, metrojateng.com, diakses pada 13 Oktober 2016. 